Dueholm, K. S., Pedersen, A. K. \& Ulff-Møller, F. 1977: High precision photogrammetric methods used in geological mapping. Rapp. Grønlands geol. Unders. 81, 53-56.

Peel, J. S. 1977: Cambrian-Silurian studies in Washington Land, western North Greenland. Rapp. Grønlands geol. Unders. 85, 30-33.

K.S.D. Instituttet for Landmåling og Fotogrammetri, Danmarks Tekniske Højskole, Landmålervej 7 , 2800 Lyngby, Denmark.

\title{
Establishment of an organic geochemical laboratory in GGU
}

\section{J. Perregaard}

For some time organic geochemical evaluation of an appreciable number of surface samples from the Cretaceous-Tertiary sediments of West Greenland was performed by companies and research institutes outside Denmark (Schiener, 1976). In order to provide immediate control of the data produced, as well as to acquire the necessary expertise within Denmark, laboratory facilities for organic geochemical analysis were set up in GGU in the spring 1977 with financial support from the Danish Natural Science Research Council (SNF). Establishing these facilities is part of an energy research project initiated by SNF in late 1973 to evaluate fossil fuel potentials of sedimentary basins in Greenland.

A field sampling programme carried out in conjunction with 'Programmgruppe für Erdöl und Organische Geochemie' (EOG), Jülich, West Germany, (see Schiener \& Leythaeuser, this report) constituted another part of the project. The material collected is presently being investigated, with the aim of assessing the organic richness of the sediments, type of organic matter deposited, degree of thermal maturation and the influence of weathering and of intrusive igneous bodies upon the composition of the organic content.

Participation in evaluating results of petroleum exploration activities (Henderson, 1977) would be an obvious future task for a suitably equipped analytical laboratory with the experience obtained from onshore studies.

\section{Laboratory set-up}

The laboratory is equipped with instrumentation for solvent extraction of crushed sediments (soxhlett and ultrasonic) and for pre-separations of the extracts (column chromatography, urea adduction, molecular sieving etc.). To improve the quality and purity of commercially available solvents distillation is performed in packed columns with silvered vacuum jackets and packing material of high efficiency (stainless steel wire-mesh rings or Wilson helices). Further analysis of separate fractions is performed on a Hewlett-Packard 5840A gaschromatograph (fig. 51) controlled from a keyboard, which also functions as an integrator. Packed glass columns $(4 \mathrm{~m})$ with an eutectic salt mixture $\left(\mathrm{KNO}_{3}, \mathrm{NaNO}_{3}\right.$, 

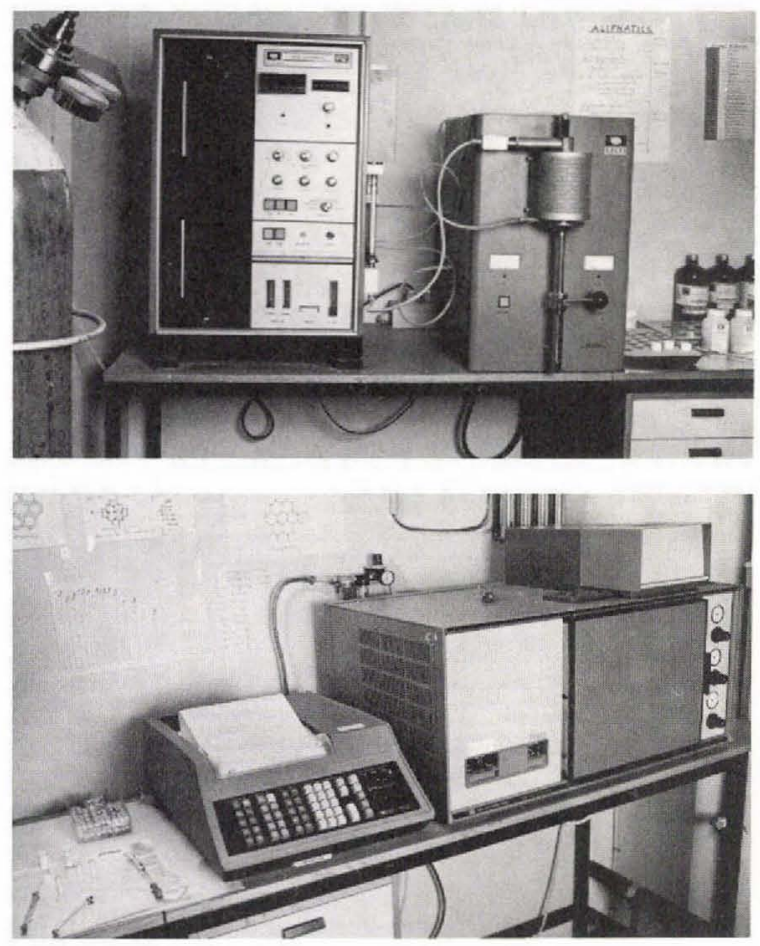

Fig. 51. Organic analytical equipment. Above: Leco IR-12 carbon determinator; below: HP $5840 \mathrm{~A}$ gaschromatograph with keyboard control/integrator/recorder unit on the left side.

$\mathrm{LiNO}_{3}$ ) as liquid phase (3-5 per cent) and chromosorb $\mathrm{G}$ (AW) as solid support permit quantitative detection of $n$-alkanes from $n-C_{9}$ up to $n-C_{40}$ without any serious column bleeding up to the maximum temperature limit of the chromatograph $\left(400^{\circ} \mathrm{C}\right)$. The organic carbon content is measured with an automatic carbon determinator (Leco IR-12) (fig. 51). Generous advice from EOG, West Germany, and Organic Geochemistry Unit, University of Newcastle, England, have been of great assistance in establishing suitable analytical instrumentation and technique within a relatively short period.

\section{Analytical procedures}

Collected samples are dried (to avoid growth of fungus) and stored in the dark with precautions taken to avoid organic contamination. Immediately before analysis the samples are finely ground ( $>90$ per cent of particles of size $<160 \mu$ ). After removal of carbonates ( $\mathrm{HCl}$ treatment) the organic carbon content $\left(\% \mathrm{C}_{\text {org }}\right)$ is determined by combustion and measuring the amount of liberated $\mathrm{CO}_{2}$ by infrared absorption (Leco-analyser, fig. 51).

The (bitumen) content of soluble organic matter (SOM) is found by soxhlett extraction with dichloromethane or chloroform. The extracts are separated by column chromatography $\left(\mathrm{Al}_{2} \mathrm{O}_{3}+\right.$ silicagel) into aliphatics (eluted with $n$-hexane), aromatics (eluted with dichloromethane), hetero compounds (eluted with methanol), and asphaltenes (retained on the 
Table 12. Techniques in use or being established at the Survey. for analysis of the organic content of Greenland sediments

Methods underlined are not available at the moment on a routine basis

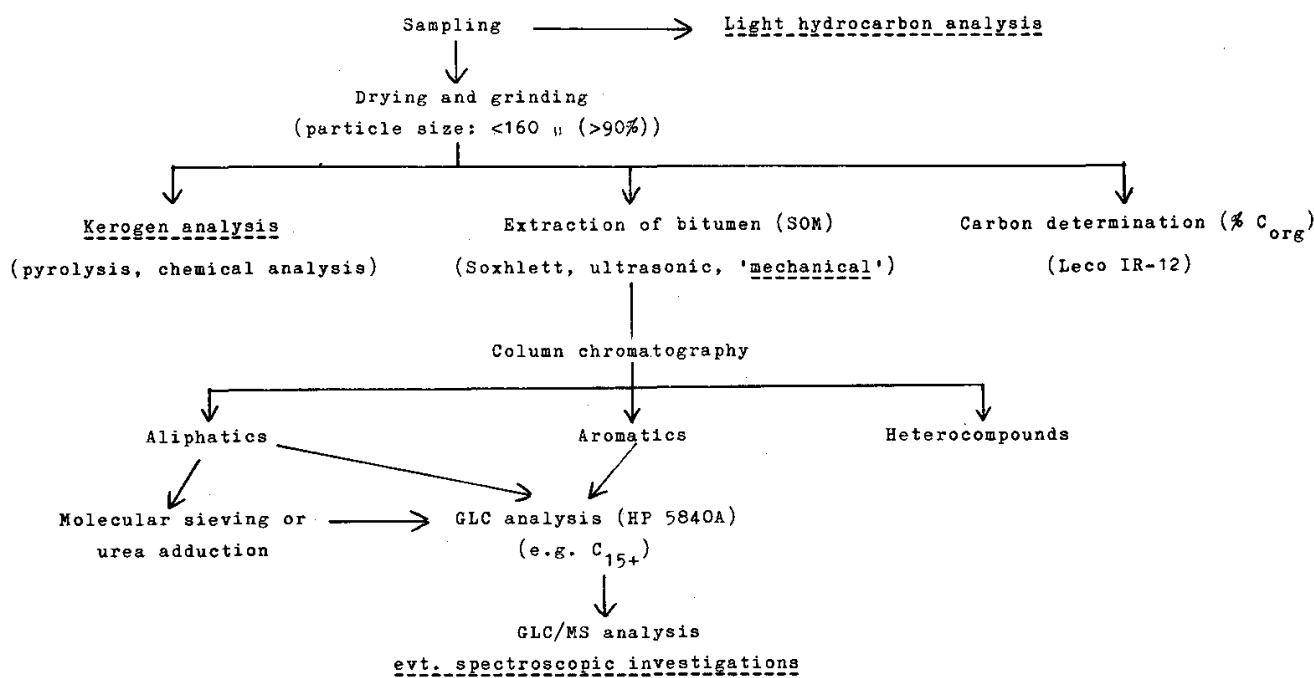

column). The cut between different fractions is decided with the help of UV and ${ }^{1} \mathrm{H}$ NMR analysis. Extracts containing less than $3 \mathrm{mg}$ are filtered through a short column $(\sim 2 \mathrm{~cm})$ with $n$-hexane for analysis of aliphatics. Molecular sieving or urea adduction separates the aliphatics into normal and isocyclic paraffins. All solvents used are distilled just before use. Extraction thimbles, filter paper, silicagel, $\mathrm{Al}_{2} \mathrm{O}_{3}$ and molecular sieves are all thoroughly washed with pure solvents before use.

Finally the $\mathrm{C}_{15+}$ (saturated hydrocarbons in the boiling range from $n-\mathrm{C}_{15}$ upwards) composition is analysed by GLC separation. A summary of the analytical procedures is shown in Table 12. Analytical methods being established or which will be introduced later on in the project have been added to this scheme.

The analyses mentioned here have all been based upon the extractable organic matter (SOM). Important additional information can be obtained by investigation of the main insoluble constituent of the organic matter - kerogen. These analyses include $\mathrm{C}, \mathrm{H}, \mathrm{O}$ determinations (Tissot et al., 1974), thermogravimetric measurements (Espitalié et al., 1973) and pyrolysis/GLC (Larter et al., 1977). The essential outcome of these studies is the Tissot diagram (Tissot et al., 1974) reflecting thermal maturity and type of organic matter (marine algal, liptinitic or humic).

\section{Preliminary results}

About 150 samples including core and surface samples have been analysed according to the previously described procedures. Most of the samples were dark shales rich in organic 


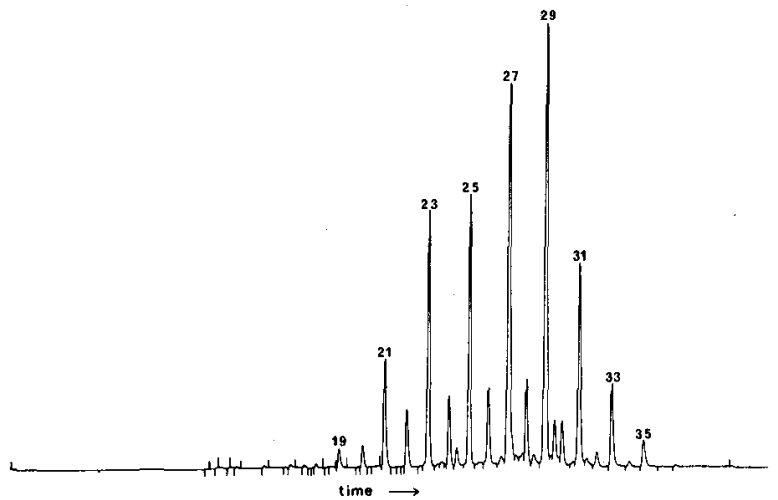

Fig. 52. GLC chromatogram of total aliphatic fraction from extract of Naujat shale sample, Sarqaqdalen, Nûgssuaq. Peak numbers correspond to chain length of $n$-alkanes.

material $\left(\mathrm{C}_{\text {org }} 3-15\right.$ per cent), but generally low in bitumen content (SOM $\left.>100 \mathrm{ppm}\right)$ and very poor in paraffins, which indicate thermally immature sediments containing organic matter of terrestrial origin. This is further confirmed by high CPI-values (carbon preference index) (Kvenvolden \& Weiser, 1967), referring to the predominance of odd over even $n$-alkanes in the range of $n-\mathrm{C}_{23}$ to $n-\mathrm{C}_{31}$, and maximum contribution from $n-\mathrm{C}_{27}$ or $n-\mathrm{C}_{29}$. An example is shown in fig. 52 which is the GLC chromatogram of the total aliphatic fraction from an organic shale $\left(\mathrm{C}_{\text {org }} 8.57\right.$ per cent) collected from the Naujat shale, Sarqaqdalen, southern Nûgssuaq.

Heated sediments (from proper burial or igneous activity) exhibit CPI-values declining towards the value 1 , found in most crude oils, and a dominant contribution of lower boiling $n$-alkanes $\left(n-\mathrm{C}_{15}\right.$ to $n-\mathrm{C}_{20}$ ). Low pristane (isoprenoid isoalkane) $/ n-\mathrm{C}_{17}$ ratios also indicate thermal influence. As an example the GLC chromatogram of the total aliphatic fraction from a dark grey shale collected on Itsako, south-eastern Svartenhuk ( $\mathrm{C}_{\text {org }} 2.71$ per cent) is shown (fig. 53). Finally 'destructive heating' results in increased contribution by the thermally more stable aromatic components. This has been observed in contact zones with igneous bodies such as dykes and sills.

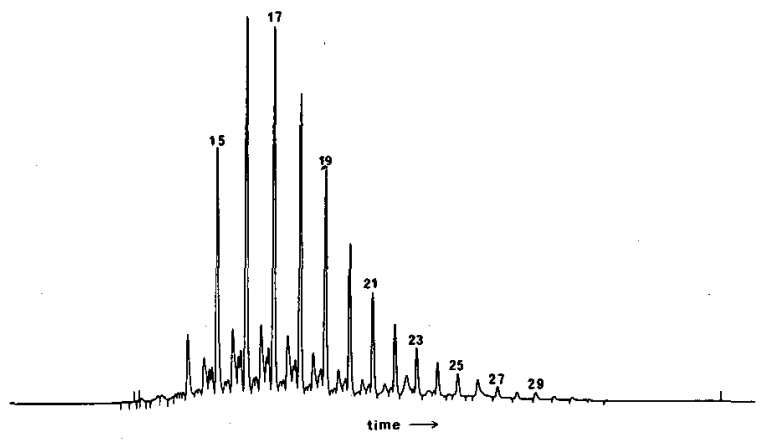

Fig. 53. GLC chromatogram of total aliphatic fraction from extract of a heated shale, Itasko, Svartenhuk. Peak numbers correspond to chain length of $n$-alkanes. 
Sediments containing organic matter of marine origin are often recognised by a more even distribution of $n$-alkanes in the range $n-\mathrm{C}_{15}$ to $n-\mathrm{C}_{31}$, or limited contribution from algal material in the $n-\mathrm{C}_{17}$ to $n-\mathrm{C}_{20}$ range (Powell et al., 1976). Attention should be paid to one of the core hole samples drilled in Sarqaqdalen (Paleocene Naujat shale), where very organic carbon rich material was obtained ( $\mathrm{C}_{\text {org }} 10-14$ per cent) with concurrent high extract values $\left(\sim 45 \mathrm{mg} / \mathrm{g} \mathrm{C}_{\text {org }}\right)$ and a high content of paraffins $(\sim 35$ per cent of total extract). The $n$-alkanes are evenly distributed over the whole range of $\mathrm{C}_{15+}$.

\section{Acknowledgements}

Financial support from the Danish Natural Science Research Council (SNF) is gratefully acknowledged.

I am much indebted to Dr. D. Leythaeuser and staff of the Programmgruppe für Erdöl und Organische Geochemie (EOG), Jülich, West Germany and to Dr. A. G. Douglas, Organic Geochemistry Unit, University of Newcastle, England, for training in analytical techniques and valuable discussions in their laboratories.

\section{References}

Espitalié, J., Durand, B., Roussel, J. C. \& Souron, C. 1973: Étude de la matière organique insoluble (kérogene) des argiles du Toarcien du bassin de Paris, II. Rev. Inst. Fr. Pétrole 28, 37-66.

Henderson, G. 1977: Developments in petroleum exploration offshore West Greenland during 1976. Rapp. Grønlands geol. Unders. 85, 33-34.

Kvenvolden, K. A. \& Weiser, D. 1967: A mathematical model of a geochemical process. Geochim. Cosmochin. Acta 31, 1281-1309.

Larter, S. R., Horsfield, B. \& Douglas, A. G. 1977: Pyrolysis as a possible means of determining the petroleum generating potential of sedimentary organic matter. In Jones, C. E. R. \& Cramers, C. A. (edit.) Analytical Pyrolysis, 189-202. Amsterdam: Elsevier Sci. Publ. Co.

Powell, T. G., Douglas, A. G. \& Allan, J. 1976: Variations in the type and distribution of organic matter in some Carboniferous sediments from northern England. Chem. Geol. 18, 137-148.

Schiener, E. J. 1976: Study of organic matter in Cretaceous-Tertiary sediments, central West Greenland. Rapp. Grønlands geol. Unders. 80, 43-49.

Tissot, B., Durand, B., Espitalié, J. \& Combaz, A. 1974: Influence of nature and diagenesis of organic matter in formation of petroleum. Bull. Amer. Petrol. Geol. 58, 499-506. 